\title{
Correction to: Assessing inequalities and regional disparities in child nutrition outcomes in India using MANUSH - a more sensitive yardstick
}

Ayushi Jain and Satish B. Agnihotri*

\section{Correction to: Int J Equity Health (2020) 19:138 \\ https://doi.org/10.1186/s12939-020-01249-6}

Following publication of the original article [1], the authors identified an error in Figs. 2 and 4. The correct figures are given below.

Published online: 07 October 2020

\section{Reference}

1. Jain A, Agnihotri SB. Assessing inequalities and regional disparities in child nutrition outcomes in India using MANUSH - a more sensitive yardstick. Int J Equity Health. 2020;19:138. https://doi.org/10.1186/s12939-020-01249-6.

The original article can be found online at https://doi.org/10.1186/s12939020-01249-6.

* Correspondence: sbagnihotri@iitb.ac.in

Technology, Bombay, Maharashtra 400076, India

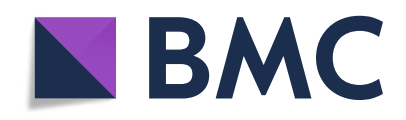

() The Author(s). 2020 Open Access This article is licensed under a Creative Commons Attribution 4.0 International License, which permits use, sharing, adaptation, distribution and reproduction in any medium or format, as long as you give appropriate credit to the original author(s) and the source, provide a link to the Creative Commons licence, and indicate if changes were made. The images or other third party material in this article are included in the article's Creative Commons licence, unless indicated otherwise in a credit line to the material. If material is not included in the article's Creative Commons licence and your intended use is not permitted by statutory regulation or exceeds the permitted use, you will need to obtain permission directly from the copyright holder. To view a copy of this licence, visit http://creativecommons.org/licenses/by/4.0/. The Creative Commons Public Domain Dedication waiver (http://creativecommons.org/publicdomain/zero/1.0/) applies to the data made available in this article, unless otherwise stated in a credit line to the data. 


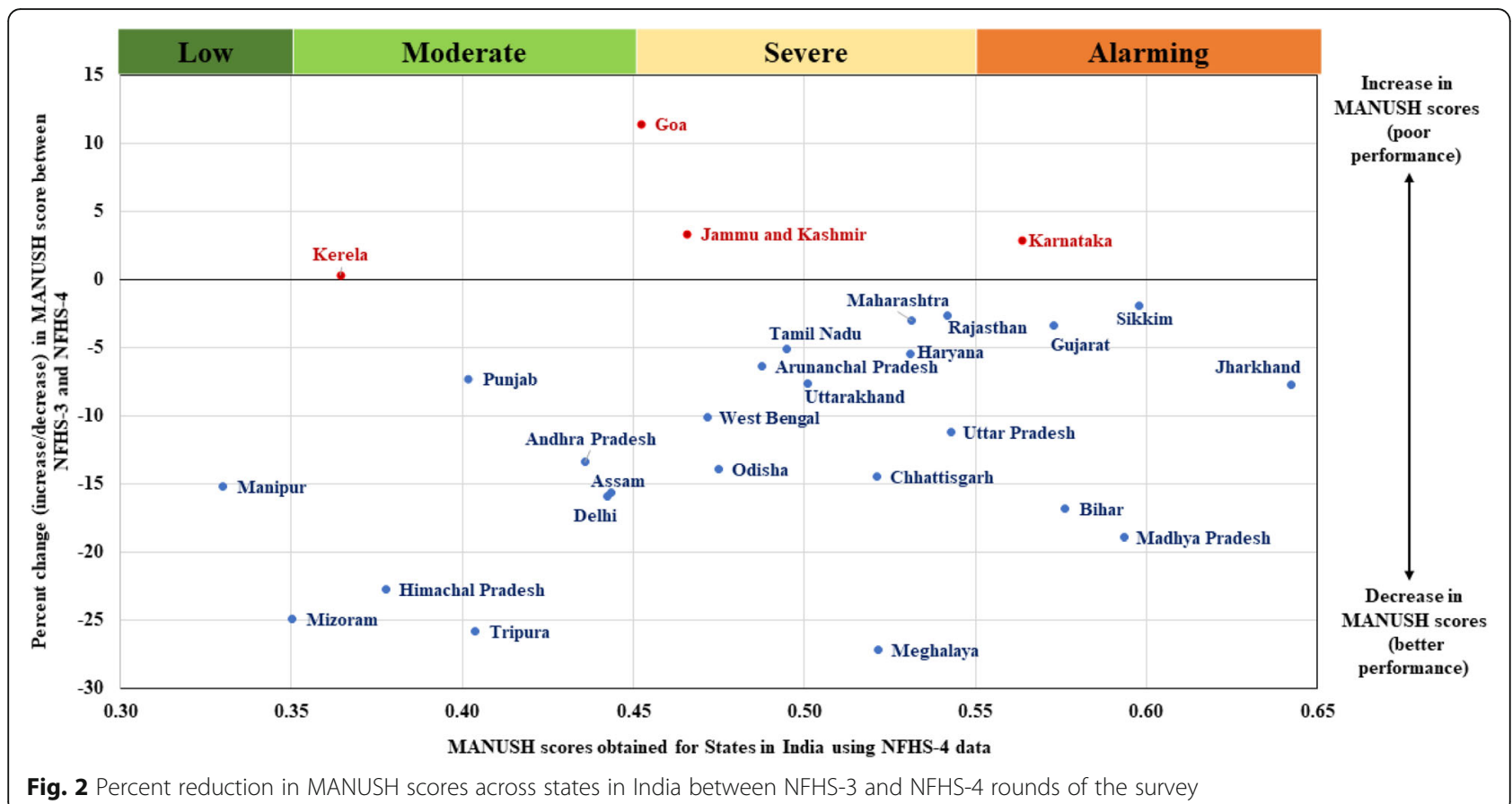

Fig. 2 Percent reduction in MANUSH scores across states in India between NFHS-3 and NFHS-4 rounds of the survey 


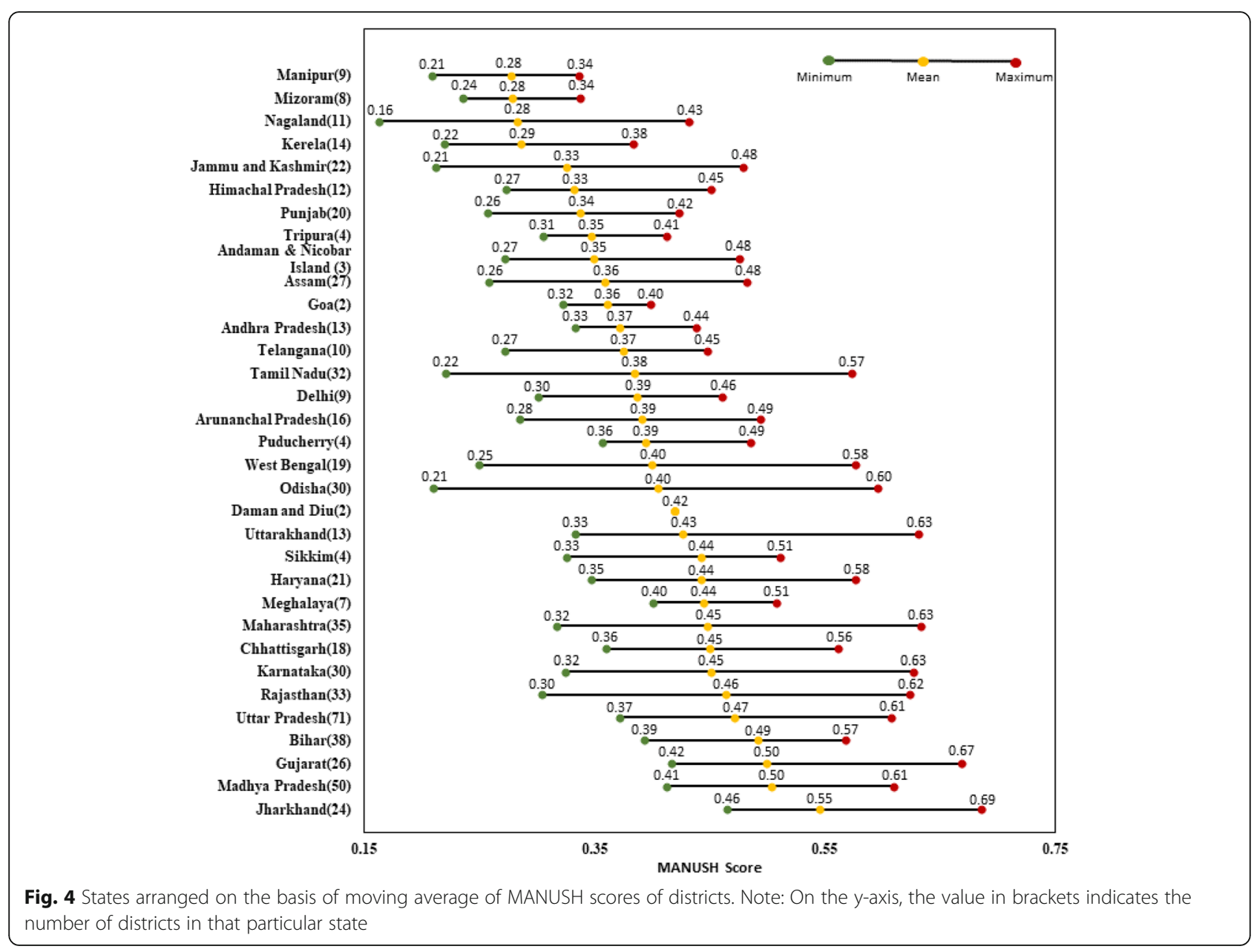

